\title{
The First Retinal Axon Growth in the Mouse Optic Chiasm: Axon Patterning and the Cellular Environment
}

\author{
Riva C. Marcus and Carol A. Mason \\ Departments of Pathology, and Anatomy and Cell Biology, Center for Neurobiology and Behavior, College of \\ Physicians and Surgeons, Columbia University, New York, New York 10032
}

The retinofugal pathway is a useful model for axon guidance because fibers from each eye project to targets on both sides of the brain. Studies using static and real time analyses in mice at E15-17 demonstrated that uncrossed axons from ventrotemporal retina diverge from crossed axons in the optic chlasm, where speclallzed resident cells may direct divergence. Other studies, however, suggest that pioneering uncrossed retinal axons derive from a different retinal region, take a different course, and enter the ipsilateral optic tract independent of fiber-fiber interactions. We examine these differences by dye-labeling the earliest optic axons and immunocytochemically identifying cells in their path.

The first optic axons arising from dorsocentral retina, enter the diencephalon at E12.5. All axons initially grow caudally, lateral to a radial glial palisade. In contrast to later growing axons, early uncrossed axons enter the ipsilateral optic tract directly. Crossed axons enter the glial palisade and course medially, then anteriorly, in a pathway corresponding to the border of an early neuronal population that expresses SSEA-1, CD44, and $\beta$-tubulin. Axon patterning occurs independent of fiber-fiber interactions from both eyes, as the first uncrossed axons enter the optic tract before crossed ones from the opposite eye. These analyses, in conjunction with our previous studies during the principal period of retinal axon growth in the diencephalon, suggest that the adult visual projection arises from agedependent variations in the types and relative contribution of cues along the path through the emerging optic chiasm.

[Key words: optic chiasm, axon guidance, midline, radial glia, SSEA-1, divergence]

The advent of improved tract tracing techniques and antigen markers of early axons has heralded a resurgence in studies on the establishment of axonal pathways in the vertebrate brain (Chitnis and Kuwada, 1990; Wilson et al., 1990; Easter et al., 1993, 1994; Chédotal et al., 1995). Aside from recent reports

Received Apr. 3, 1995; revised June 5, 1995; accepted June 7, 1995.

We thank Drs. Jane Dodd, Mary Morrison, and Pierre Godement for critically reading the manuscript and Drs. Steve Easter, Ray Guillery, David Sretavan, and Li-Chong Wang for stimulating and insightful discussions. We also thank Dis. Jane Dudd, Tony Frankfurter, Jean-Paul Misson, and Charles Underhill for supplying us with antibodies. Support was provided by NRSA F32 EY06510 (R.C.M.), NIH Grant NS27615 (Jacob Javits Award, C.A.M.), and Program Project NS30532.

Correspondence should be addressed to Dr. Carol Mason, Department of Pathology, Columbia University College of Physicians and Surgeons, 630 West 168th Street, Room 14-509, New York, NY 10032.

Copyright (C) 1995 Society for Neuroscience $0270-6474 / 95 / 156389-14 \$ 05.00 / 0$ indicating that boundaries of gene expression may influence patterns of axon growth (Figdor and Stern, 1993; Wilson et al., 1993; Macdonald et al., 1994), little information exists on cells and molecules residing within axonal paths in the brain, in particular with respect to the first growing axons (Silver, 1984; Silver and Rutishauser, 1984; Wilson and Easter, 1991).

In mammals, the retina sends both crossed and uncrossed projections to visual targets in the brain (Polyak, 1957; Guillery, 1982). Crossed and uncrossed retinal ganglion cells in the adult visual pathway derive from defined regions of the retina (Dräger, 1985; Godement et al., 1987b; Colello and Guillery, 1990; Sretavan, 1990). Dye-labeling of axons in static and living mouse tissue at E15-17 reveals that all optic axons, regardless of destination, first grow toward the midline. Growth cones on crossed axons cross the midline, whereas those on uncrossed axons become complex and turn away from the midline back toward the ipsilateral optic tract (Godement ct al., 1987b; Sretavan, 1990). A cellular specialization is centered around the chiasmatic midline (Marcus et al., 1995). This specialization consists of a palisade of radial glia intersected by a narrow midline raphe of cells arising from a band of early neurons posterior to the optic chiasm. Retinal axon divergence occurs within this specialization, consistent with the hypothesis that divergence cues are located in this zone.

While these studies demonstrate that the adult pattern of optic axon projections arises during embryonic devclopment, other observations suggest that the earliest axonal growth pattern differs from the adult pattern in three respects. First, the earliest uncrossed axons arise from dorsocentral and not ventrotemporal retina (Godement et al., 1987b; Colello and Guillery, 1990; Chan et al., 1993; Baker and Colello, 1994). Second, early uncrossed axons appear to grow directly into the ipsilateral optic tract, without first growing toward the midline (Silver, 1984; Godement et al., 1987b; Colello and Guillery, 1990). Third, interactions between axons from both eyes, apparently critical for the uncrossed path of ventrotemporal retinal axons (Godement et al., 1987a; Chan and Guillery, 1993), may be unnecessary for pathways taken by earlier axons (Sretavan and Reichardt, 1993). We expand these observations by providing details on the pattern of early retinal axon growth with respect to the cellular architecture of the nascent chiasm.

Our results demonstrate that distinct mechanisms influence optic axon trajectory during early and later development. This work provides a framework for analyzing how patterns of gene expression in the retina (Kaprielian and Patterson, 1994; Savitt et al., 1995) and forebrain (Figdor and Stern, 1993; Puelles and Rubenstein, 1993; Hatini et al., 1994; Tole and Patterson, 1995) 


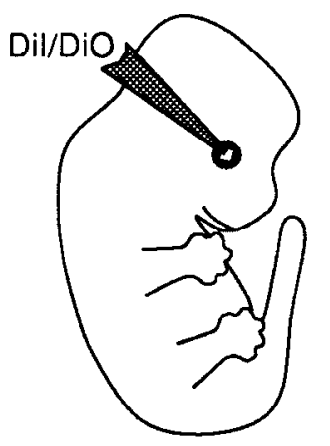

$E 12.5-E 13.5$

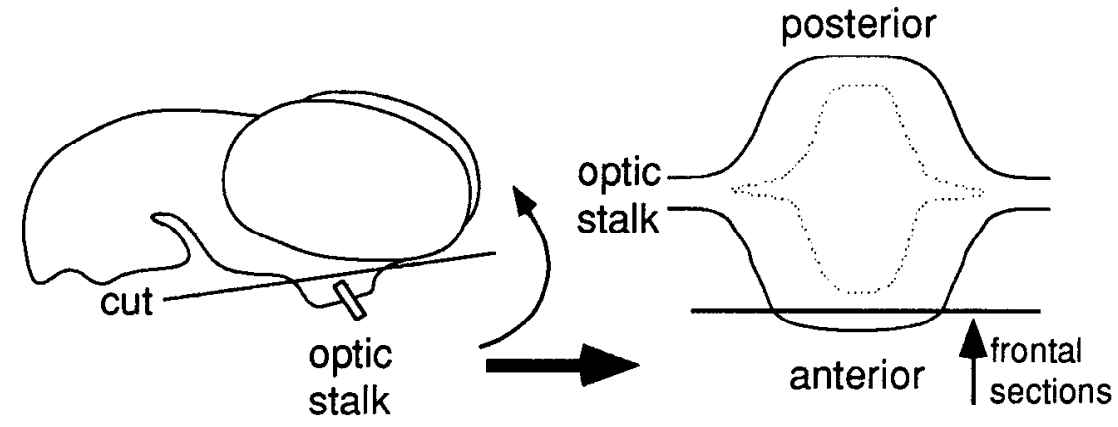

Wholemount of the
ventral diencephalon
(Horizontal view)

Figure 1. Methods. Dil and DiO were applied to the optic nerve head in the right and left eyes, respectively, of fixed embryos between E12.5 and E13.5. The brain, including the optic stalks, was dissected free, and the region overlying the third ventricle removed. Preparations were viewed both as wholemounts and in frontal sections. Double-labeling of photoconverted, dye-labeled preparations was performed as detailed in Materials and Methods. The dotted line indicates the location of the third ventricle.

relate to retinal topographic specification, axonal patterning, and regional identity in the brain.

\section{Materials and Methods}

All experiments were carried out with $\mathrm{C} 57 \mathrm{~B} 1 / 6 \mathrm{~J}$ mice from a timedpregnancy breeding colony in this department. The time of conception was considered midnight before the day on which a plug was found, and noon the following day embryonic day 0.5 (E0.5). Because developmental rates vary between pups from different mothers and within individual litters (see Easter et al., 1993), embryos were grouped according to the degree of retinal axon growth rather than absolute age.

Pregnant mothers containing embryos between the ages of E11.5E13.5 were anesthetized with a mixture of ketamine and xylazine, and the embryos removed one at a time by caesarean section. Embryos older than E12.5 were perfused transcardially with $4 \%$ paraformaldehyde in $0.1 \mathrm{M}$ phosphate buffer. Younger embryos were fixed by immersion in the same fixative. After fixation for four hours at room temperature or overnight at $4^{\circ} \mathrm{C}$, the tissue was washed and stored in phosphate buffer.

\section{DiI labeling of retinal axons in fixed tissue}

Crystals of DiI (1,1'-dioctadecyl-3,3,3',3'-tetramethylindocarbocyanine perchlorate) and $\mathrm{DiO}$ (3,3'-dioctadecyloxacarbocyanine perchlorate) were applied to the optic nerve head of the right and left eyes, respectively. Dye was applied to the optic nerve head to ensure labeling of the maximum number of optic axons. The tissue was stored in the dark at room temperature in phosphate buffer containing sodium azide for 5-7 d to allow transport of the dye.

Dye-labeled optic axons were visualized in wholemounts. The optic stalks and the region of the ventral dicnecphalon, which includes the presumptive optic chiasm, were dissected free (Fig. 1) and the preparation mounted between two coverslips, using two or three smaller coverslips as spacers. Whole mount preparations, which graphically demonstrated the course of the earliest axons, were viewed with fluorescent illumination on a Zeiss Axioplan microscope.

Photooxidation of DiI. DiI was photoconverted from a fluorescent compound as described previously (Marcus et al., 1995). Photooxidation was performed by illuminating the DiI-labeled axons using a $10 \times \mathrm{Neo}-$ fluor objective and a $100 \mathrm{~W}$ mercury lamp, on a Nikon Optiphot microscope fitted with fluorescent illumination appropriate for rhodamine and Dil. Typically $30-40 \mathrm{~min}$ of fluorescent illumination were required to obtain a good reaction product. Following photoconversion, labeled axons were drawn with the aid of a camera lucida attachment.

\section{Immunocytochemistry}

Antibodies. Radial glia were visualized by immunostaining with monoclonal antibody RC2 (mouse IgM), which was originally a gift of Dr.
J.-P. Misson and V. Caviness (Massachusetts General Hospital). MAb RC2 specifically stains immature astrocytes in the mouse CNS (Misson et al., 1988) and a midline palisade of radial glia in the optic chiasm of E15-E17 mice (Marcus et al., 1995).

Monoclonal antibody 480-1.1 (mouse IgM) was obtained from the Developmental Studies Hybridoma Bank (Solter and Knowles, 1978). This antibody recognizes stage-specific embryonic antigen 1 (SSEA-1), expressed by early embryonic stem cells and human granulocytes (Knowles et al., 1982), by the floor plate and radial glia in the spinal cord (Dodd and Jessell, 1985; Dodd, personal communication), and by a group of cells in the ventral diencephalon in mice at E15-E17 (Marcus et al., 1995).

CD44 is a T-cell antigen found in the immune system (Denning et al., 1990; Tanaka et al., 1993) and in the developing optic chiasm (Sretavan, 1993; Sretavan et al., 1994). CD44-positive cells were visualized by the KM201 antibody (rat IgG) generously provided by Dr. C. Underhill (Georgetown).

Neurons were visualized using the TuJ1 antibody (mouse IgG), generously provided by Dr. A. Frankfurter (University of Virgina). Monoclonal antibody $\mathrm{TuJ} 1$ recognizes an antigen present on neuron-specific class III $\beta$-tubulin (Lee et al., 1990) and appears to recognize all early axons and neuronal cell bodies in the mouse CNS (Easter et al., 1993).

Immunostaining. Immunostaining was performed on both sections and wholemounts (Fig. 1). Wholemounts with and without Dil-photoconverted axons were incubated in blocking buffer $[0.1 \mathrm{M}$ phosphate buffer containing $5 \%$ normal goat serum (NGS) and $0.5 \%$ Triton X-100 (Sigma)] for $1 \mathrm{hr}$ to block nonspecific binding. The preparations were then incubated in the primary antibody diluted in blocking buffer for 1 $\mathrm{d}$, followed by six $30 \mathrm{~min}$ washes in phosphate buffer. Following 1 hour in blocking buffer the preparations were then incubated in the appropriate peroxidase-conjugated secondary antibody (diluted 1:100 in blocking buffer) overnight. Preparations were washed six times in phosphate buffer, rinsed in distilled water, and then incubated in a solution containing $0.8 \mathrm{mg} / \mathrm{ml} \mathrm{DAB}$ plus $0.05 \% \mathrm{NiCl} 2$ for $30 \mathrm{~min}$. A blue-black reaction product was visualized following the addition of $0.005 \%$ hydrogen peroxide. All steps were carried out at room temperature.

Double-labeled wholemounts were mounted as above, examined using transmitted light, and photographed or drawn through a camera lucida. Selected preparations were subsequently embedded in agar and cut either frontally or horizontally at $50 \mu \mathrm{m}$ on a vibratome. Sections were mounted onto subbed slides and allowed to dry. After dehydration in ethanol and clearing in xylene, sections were coverslipped with PerInount.

Both vibratome sections and frozen sections from embryos not previously labeled with Dil were immunostained. Vibratome sections were prepared as above. Frozen sections $(10-20 \mu \mathrm{m})$ were cut from brains impregnated with $20 \%$ sucrose in phosphate buffer overnight at $4{ }^{\circ} \mathrm{C}$ and embedded in TBS tissue freezing medium (Triangle Biomedical Sciences). Sections were immunostained as described for the whole mounts 


\section{$E 12.5-E 12.75$}
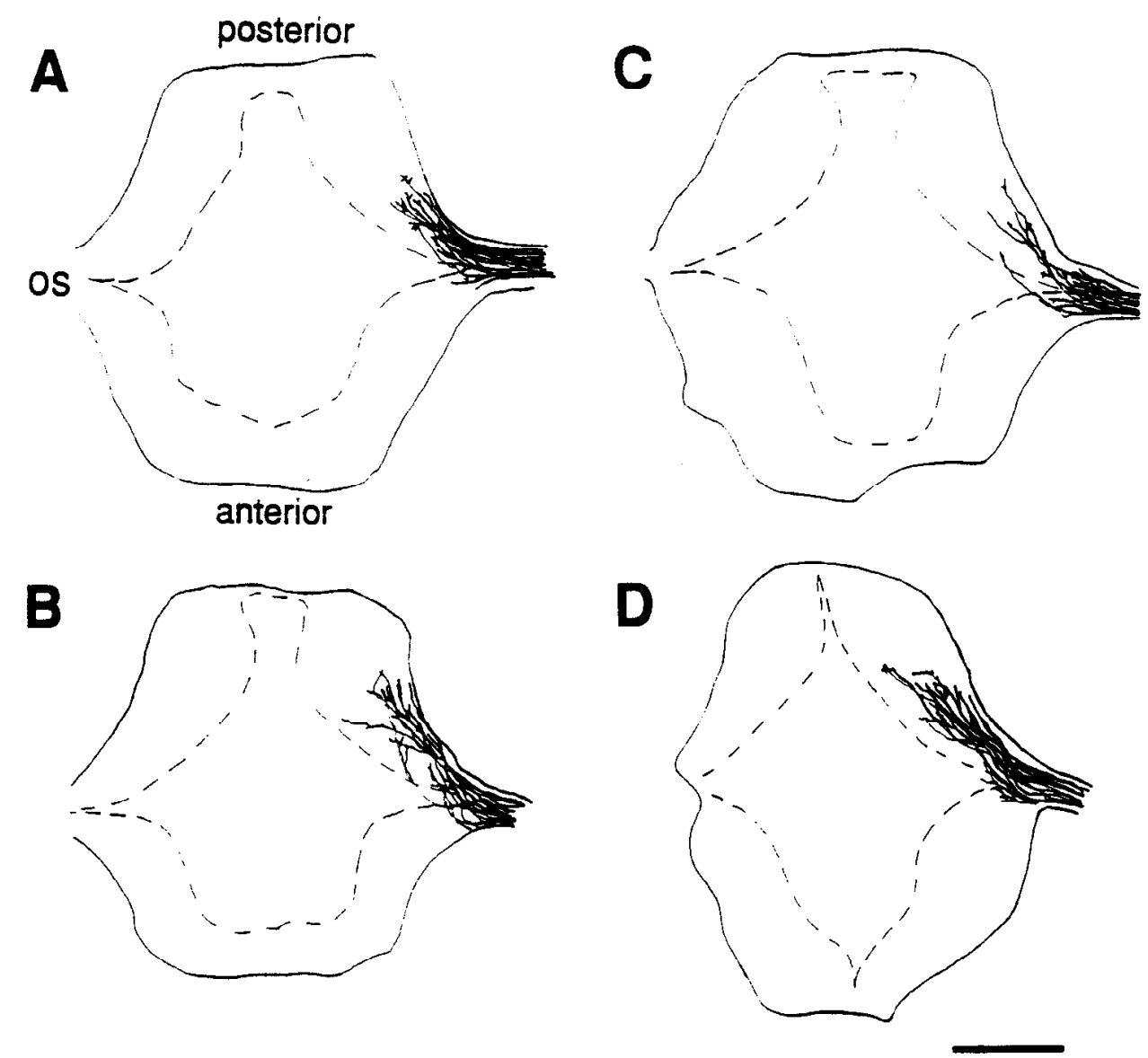

Figure 2. Camera lucida drawings of wholemount preparations demonstrating the initial growth of retinal axons in the lateral ventral diencephalon. Dashed lines indicate the location of the third ventricle. os, Optic stalk. Scale bar, $300 \mu \mathrm{m}$. above, except that sections were incubated in peroxidase or fluorescently conjugated secondary antibodies for $60 \mathrm{~min}$ at room temperature.

Preparations were viewed and photographed on a Zeiss Axiophot microscope equipped with fluorescence and DIC optics. In all, more than 70 preparations were labeled with DiI. Most of these were subsequently processed immunocytochemically.

\section{Results}

The early projection pattern of optic axons

Previous studies have shown that crossed axons originate throughout the retina, whereas the adult uncrossed projection originates primarily from ventrotemporal retina (Dräger, 1985; Godement et al., 1987b; Colello and Guillery, 1990; Sretavan, 1990). In contrast, the first optic axons to leave the eye originate in dorsocentral retina and include axons destined to both cross and not cross the midline (Godement et al., 1987b; Colello and Guillery, 1990; Chan and Guillery, 1993; Baker and Colello, 1994). Axons anterogradely labeled from the optic nerve head enter the rostroventral base of the diencephalon between E12.5E12.75. The optic stalks extend at right angles from the brain, and axons leaving the optic stalks and entering the brain turn caudally at this juncture (Fig. 2 and see Fig. 5-1; see also Silver, 1984). Following this turn, axons and their growth cones extend posteriorly in the lateral portion of the brain, close to the pial surface (Fig. 2). During this growth period axons are not tightly fasciculated and there are no clear distinctions in the order, path- way, or trajectory of the labeled axons which distinguish crossed from uncrossed fibers.

Between E12.75 and E13.5 many more axons grow into the brain and the trajectories of crossed and uncrossed axons can be distinguished. The site of the future optic chiasm, is caudal to the juncture of the optic stalk with the brain. At first, after turning caudally, all optic axons follow a straight trajectory as they course posteriorly in the ventral diencephalon (Fig. 3). In 24 of 28 preparations $(86 \%)$ which had axons clearly turning toward the midline, a small number of ipsilaterally directed axons were apparent. After continuing posteriorly in the lateral portion of the brain, ipsilaterally projecting axons grow toward and directly into the ipsilateral optic tract. In wholemounts the separation of crossed and uncrossed axons was sometimes difficult to discern because of the broad distribution of optic axons posterior to the juncture of the optic stalks with the brain. In frontal sections through these preparations, however, uncrossed fibers are clearly visible as they begin their "dorsal climb" in the ipsilateral optic tract (e.g., Fig. 7B). This pattern contrasts with that seen at E1517 , where uncrossed axons first grow medially within the chiasm before sharply turning back toward the ipsilateral optic tract (see Godement et al., 1990; Fig. 12).

Crossed axons follow an indirect path en route to the contralateral optic tract. After initially growing posteriorly in the lateral diencephalon, crossed axons turn toward the midline. Cross- 


\section{$E 12.75-E 13.5$}
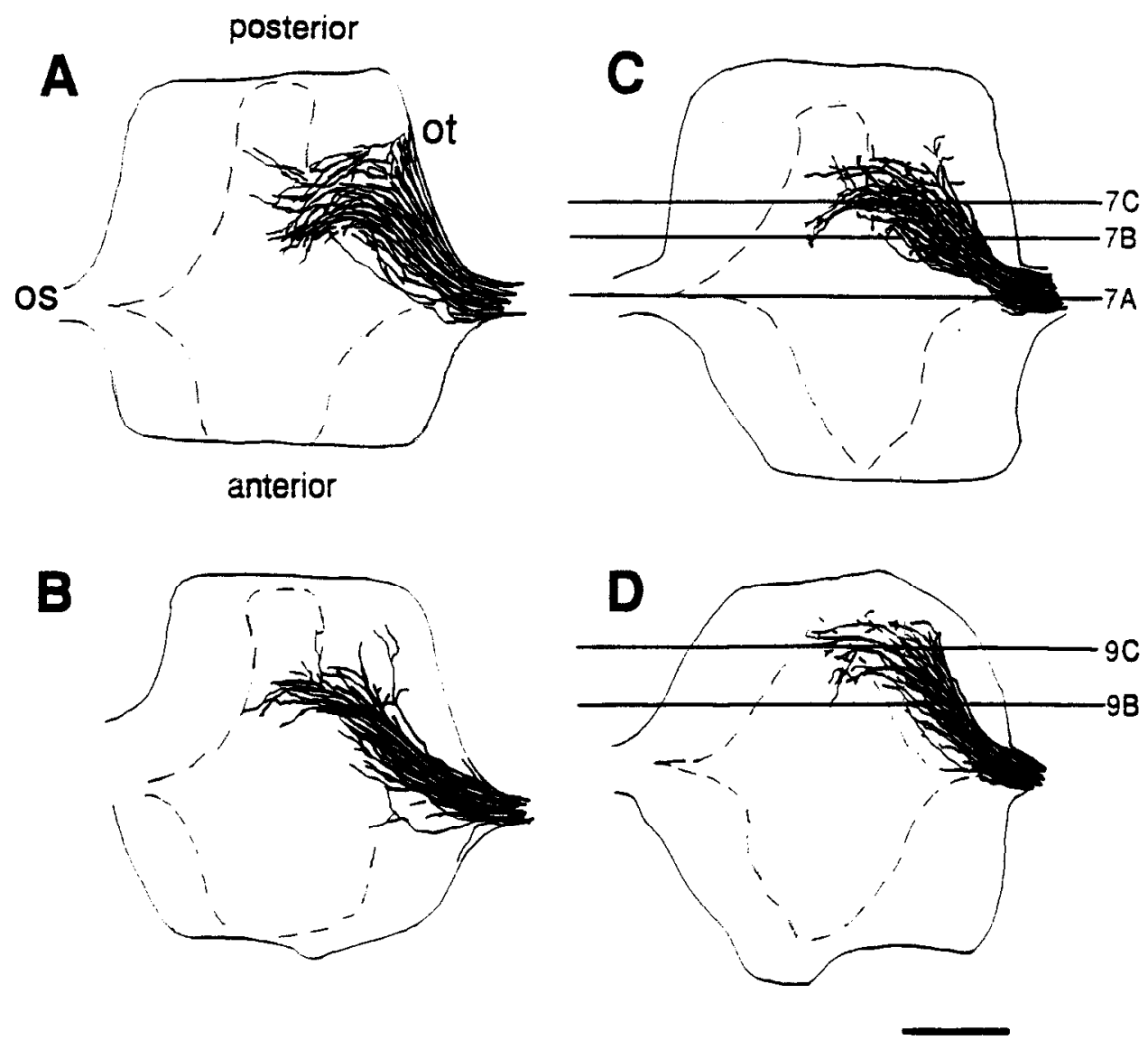

Figure 3. Camera lucida drawings of wholemount preparations from E12.75E13.5 embryos. Uncrossed axons segregate from crossed axons in the posterolateral portion of the diencephalon. Crossed axons turn first medially and then anteriorly as they course toward the midline. The horizontal lines in $C$ and $D$ indicate the plane of section in photomicrographs of these preparations shown in Figures 7 and 9, respectively. Dashed lines indicate the location of the third ventricle. Abbreviations: os, optic stalk; ot, optic tract. Scale bar, $300 \mu \mathrm{m}$.

ing axons both proceed directly across the neuraxis and into the presumptive contralateral optic tract and turn anteriorly as they approach the midline (Fig. 3). In 18 of 21 preparations (86\%) with axons at the midline itself, crossed axons clearly curved anteriorly. In contrast, later-arriving crossed axons traverse the chiasmatic midline diagonally, parallel to the axis of the optic nerve, which shifts rostrally and medially during development (Marcus et al., 1995; see Fig. 12).

Previous studies suggest that interactions between fibers from both eyes are necessary for the normal development of the uncrossed pathway (Godement et al., 1987a, 1990; but also see Sretavan and Reichardt, 1993). Therefore, we injected DiI and $\mathrm{DiO}$ into the right and left eyes, respectively, in order to analyze whether fiber-fiber interactions between axons from the two cycs occur during the earliest period of growth into the presumptive chiasm. In all of the 16 preparations examined in this manner, optic axons from a given eye entered the ipsilateral optic tract before axons from the contralateral eye crossed the midline (Fig. 4). Axons arising from dorsocentral retina, therefore, enter the ipsilateral optic tract independent of interactions with axons from the opposite eye. In addition, fibers from the two eyes do not appear to fasciculate with one another once in the optic tract (Fig. $4 C$ ). The close proximity of crossed and uncrossed axons once in the optic tract, however, indicates that interactions between crossed and uncrossed axons may occur at this point. Thus, fiber-fiber interactions between axons from the two eyes are not important for the establishment of the initial ipsilateral projection, as suggested by Sretavan and Reichardt (1993; see also Godement et al., 1987b). In general uncrossed axons constitute approximately $5-10 \%$ of the total number of axons. This small number is not surprising since in that the adult the average number of ipsilaterally projecting axons is less than $3 \%$ of the total population (Rice et al., 1995).

The initial pattern of growth of optic axons into the ventral diencephalon is summarized in Figure 5. First, at the juncture of the optic stalk with the brain all retinal axons turn caudal, orthogonal to their direction of growth in the optic stalk (Fig. 5-1). Second, all optic axons, regardless of destination, initially grow posteriorly in the lateral portion of the brain (Fig. 5-2). Third, after continuing posteriorly in the lateral ventral diencephalon, crossed axons turn toward the midline (Fig. 5-3). Fourth, rather than entering the contralateral optic tract directly, many optic axons course rostrally, only then crossing the midline rather anteriorly (Fig. 5-4). Finally, optic axons are observed in the ipsilateral optic tract prior to contact with axons from the contralateral eye (Fig. 5-*), indicating that fiber-fiber interactions are not necessary for the establishment of the earliest ipsilateral projection. Taken together, these results are consistent with the hypothesis that multiple cues, located within the ventral diencephalon, play a role in shaping optic axon trajectory in the developing optic chiasm (Godement et al., 1990, 1994; Sretavan et al., 1994; Marcus et al., 1995). Moreover, because all five of these features differ from the patterns seen at E15-17, these results suggest that guidance cues involved in the establishment 

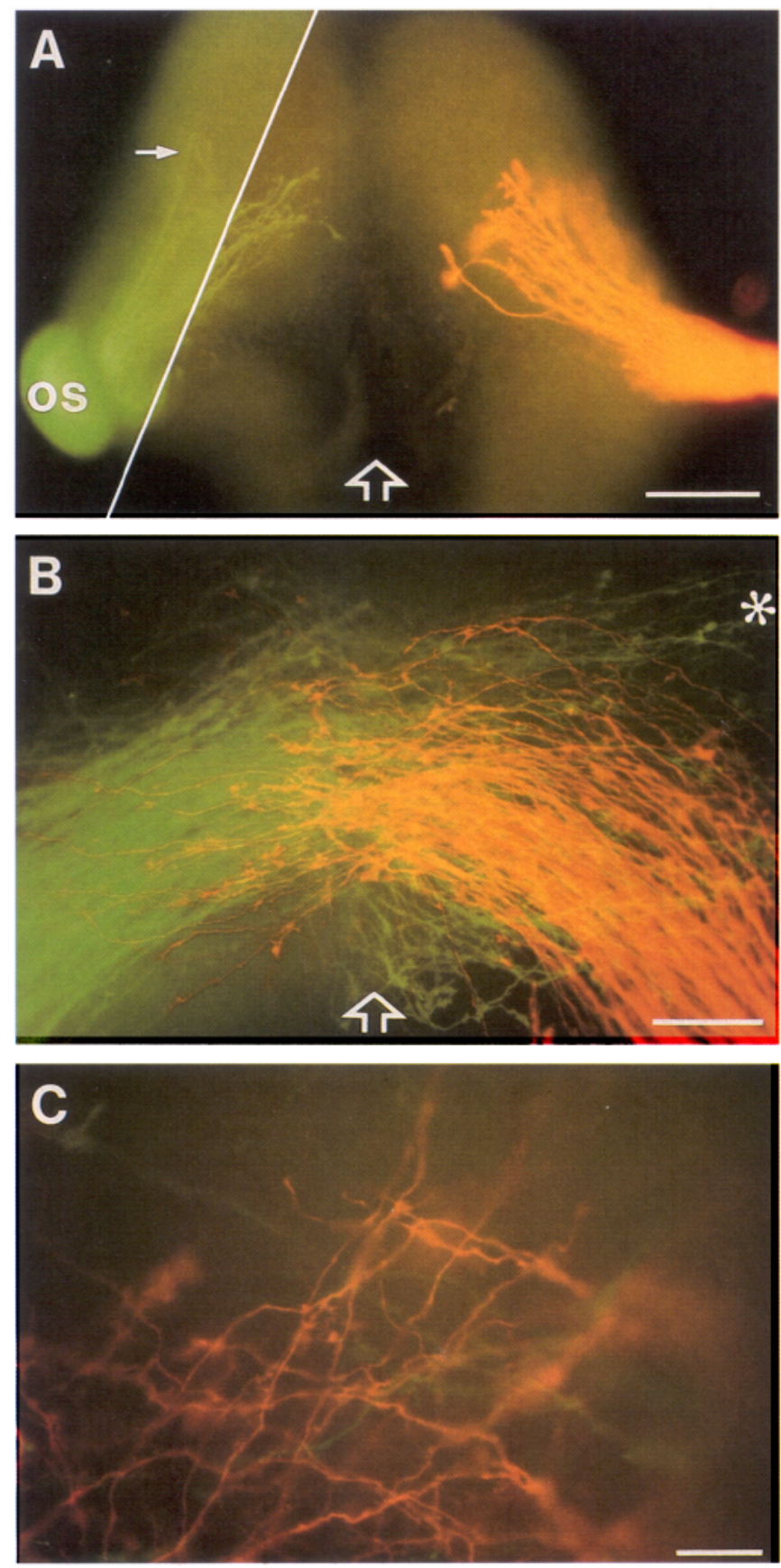

Figure 4. Fiber-fiber interactions are not involved in the establishment of the optic chiasm. Wholemount preparations in which DiI and $\mathrm{DiO}$ were inserted in the optic nerve head of the right and left eyes, respectively. Anterior is down, and the open arrows in $A$ and $B$ indicate the midline. $A$, Axons enter the ipsilateral optic tract (arrow) prior to contact with crossed axons from the opposite eye. $B$, At a later stage crossed axons course medially and then anteriorly en route to the contralateral optic tract. $C$, High power view of axons in the optic tract to the right of the asterisk in $B$, Crossed axons do not fasciculate with uncrossed axons in the optic tract. Scale bars: $A, 200 \mu \mathrm{m} ; B, 100 \mu \mathrm{m}$; $C, 25 \mu \mathrm{m}$.

of the visual projection may differ from those acting at later ages.

\section{Cellular components of the developing optic chiasm}

Analysis of the DiI-labeled retinal axons identificd potential loci for cues that govern the early pattern of growth. To investigate cellular components in the ventral diencephalon that may contribute to these patterns, we used several different antigen markers, with our study of later stages (E15-17) of retinal axon growth as a guide (Marcus et al., 1995). The relationship of the pattern of ingrowing axons to identified cellular components of the chiasm was analyzed in preparations containing both dyelabeled axons and immunolabeled cells.

Radial glia occupy the ventral diencephalon. Our previous studies at E15-E17 revealed a dense grouping of radial glia in the optic chiasm, the radial glial "palisade" (Marcus et al., 1995). At E12.5, MAb RC2 labels a grouping of radial cells centered around the midline, that extend between the floor of the third ventricle and the pial surface of the brain (Fig. 6). Labeled cells are absent from the optic stalks and few labeled cells are in the lateral diencephalon adjacent to where the optic stalks join the brain. About $150-200 \mu \mathrm{m}$ caudal to this point, RC2-positive cells fan out and occupy the entire extent of the ventral diencephalon, thereby demarcating the posterior boundary of the radial glial palisade. Here, labeled endfeet and processes near the pial surface are less densely packed than those along the ventricular lining, possibly reflecting branching of the radial fibers along the pial surface, as seen in the cerebral cortex (Takahashi et al., 1990).

As viewed in frontal sections, at E12.5 the radial glial palisade extends $350-450 \mu \mathrm{m}$ to either side of the midline (Fig. 6). In contrast, at E15-17 the palisade occupies a region approximately 150-200 $\mu \mathrm{m}$ to either side of the midline. RC2-labeled fibers occupy approximately $65 \%$ of the area between the optic stalks at E12.5-E13.5 compared to approximately $50 \%$ of the area between the juncture of the optic nerves with the brain at E15E17. The relatively smaller area occupied by RC2-positive fibers at E15-E17 is likely due to a combination of two factors. First, as development proceeds, the width of the basal portion of the ventral diencephalon becomes narrower. Second, RC2-labeled fibers become more restricted around the midline at older ages. This restriction may be similar to the age-related shift in the border between interfascicular glia of the optic stalk and radial glia in the optic chiasm in the developing ferret (Guillery and Walsh, 1987).

In preparations containing both DiI photoconverted axons and RC2-labeled cells, optic axons enter and initially grow posteriorly, lateral to the radial glial palisade (Fig. 7A). Contralaterally projecting axons turn medially near the boundary between the caudal palisade and the RC2-positive zone in the posterior ventral diencephalon. At this point they enter and grow among the RC2-positive cells of the palisade. Many uncrossed axons grow rostrally as they approach the midline before reorienting back toward the developing contralateral optic tract. Growth cones of uncrossed axons do not enter the radial glial palisade, but rather enter the ventrolateral portion of the RC2-positive zone caudal to the palisade itself. There they grow among the more loosely packed processes of the radial glia at the pial surface (inset Fig. $7 C$ ). Thus, in areas that are both $\mathrm{RC} 2$-positive and -negative, both crossed and uncrossed optic axons grow almost exclusively outside of regions containing RC2-positive cells. Growth cones only enter RC2-positive regions when they reach the RC2-occupied zone at the caudal boundary of the palisade. The restricted growth of optic axons in RC2-negative regions suggests that the RC2-positive palisade may help shape the initial pathway taken by optic axons, creating a region less favorable for optic axon growth.

Antigens associated with midline specializations are ex- 


\section{Early Pattern of Optic Axon Growth}

Figure 5. Schematic diagram depicting the early pattern of optic axon growth. See Results for details. Abbreviations: $D C$, dorsocentral retina; $O T$, optic tract.

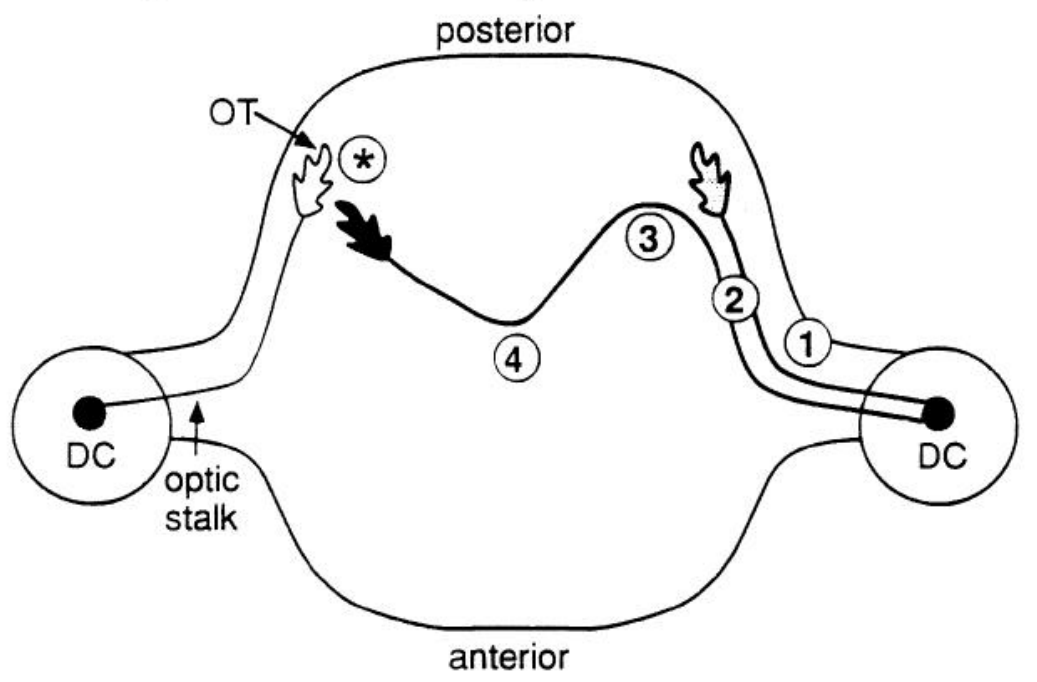

tral to cell bodies along the ventricular lining and near, but not contacting the pial surface (Fig. $8 B, C$ ). Numerous processes extend from round, labeled cell bodies within this zone (Fig. $8 B$ ). In addition, many SSEA-1-positive radial processes contact the ventricular surface (e.g., Fig. 9C).

Because of the striking similarity between this pattern and a cellular pattern reported to be both MAP2- and CD44-positive (Sretavan et al., 1994) sections were double-labeled with antibodies against SSEA-1 and CD44. Both antibodies label a similar palette of cells in the developing optic chiasm (Fig. 10). However, whereas all SSEA-1-positive cells appear to be CD44positive, CD44 labels additional, SSEA-1-negative cells.

As described earlier, many of the first axons to cross the midline do not enter the contralateral optic tract directly, but instead take a more indirect route, turning first medially and then rostrally before reorienting back toward the contralateral optic tract. In whole mounts containing both DiI-photoconverted axons and SSEA-1-immunolabeled cells, the course of the optic axons
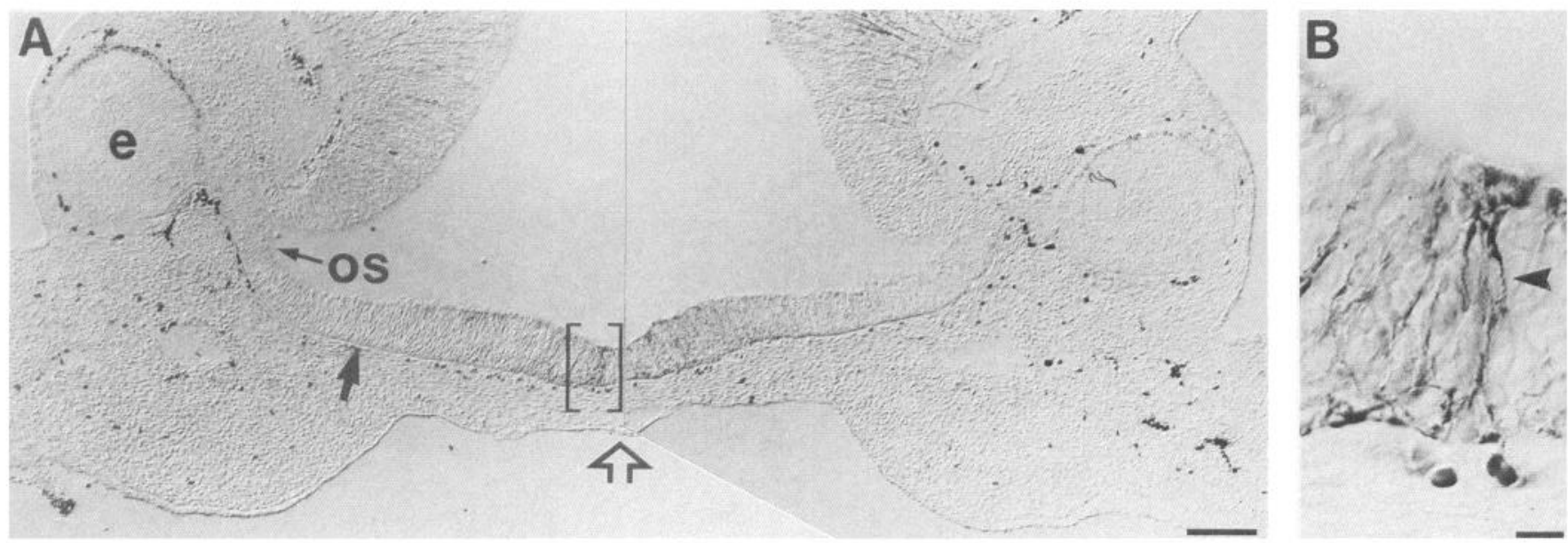

Figure 6. A palisade of radial glia straddles the midline of the developing optic chiasm. $A$ and $B$, Frozen, frontal section from an E12.5 embryo immunolabeled with the RC2 antibody. RC2-positive cells extend from the ventricular to the subpial surface of the brain on either side of the midline (open arrow). Both the optic stalks and the lateral ventral diencephalon (solid arrow) are devoid of RC2-labeling. B is a magnification of the bracketed region in A. An arrowhead points to the cell body of an RC2-labeled cell. Dark, round cells outside of the nervous system are blood cells which are nonspecifically labeled. Abbreviations: $e$, eye; os, optic stalk. Scale bars: $A, 100 \mu \mathrm{m} ; B, 10 \mu \mathrm{m}$. 

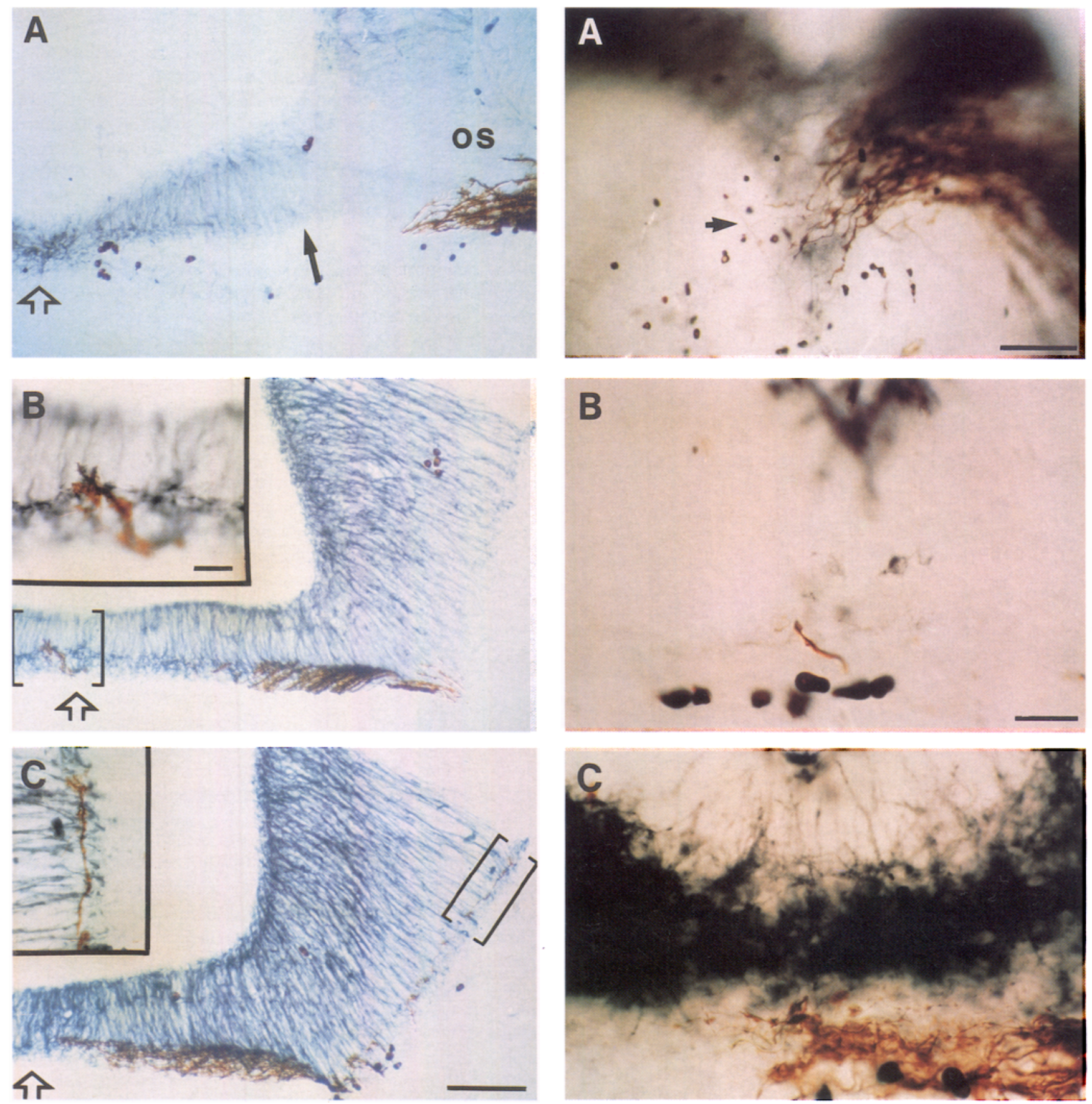

Figure 7 (left). Crossed and uncrossed axons relate differently to the radial glial palisade. Frontal sections through an E12.75 embryo containing both DiI, photoconverted axons (brown) and RC2-positive radial glia (blue). A camera lucida drawing of the dye-labeled axons indicating the planes of section in $A-C$ is shown in Figure $3 C$, and the midline in each section is indicated by an open arrow. $A$, Optic axons enter the ventral diencephalon and grow posteriorly lateral to a palisade of RC2-positive glia. $B, 250 \mu \mathrm{m}$ caudal to $A$. Caudal to the juncture between the optic stalks and the brain, crossed axons turn medially and rostrally as they enter the radial glial palisade. The inset shows a growth cone which has just crossed the midline, growing among RC2-positive subpial endfeet. $C, 350 \mu \mathrm{m}$ caudal to $A$. Uncrossed axons enter the ipsilateral optic tract directly where they grow among the subpial endfeet of radial glia that are caudal to the radial glial palisade straddling the chiasmatic midline. Brackets indicate the areas in the insets. Abbreviation: os, optic stalk. Scale bars: $A-C, 100 \mu \mathrm{m}$; insets, $25 \mu \mathrm{m}$.

Figure 9 (right). Crossed axons course under and around a population of SSEA-1-positive cells in the developing chiasm. Wholemount ( $A$ ) and frontal sections $(B, C)$ through E12.75 embryos containing both DiI, photoconverted axons (brown) and SSEA-1-positive cells (blue). $A$, The medial and anterior trajectories taken by crossed axons corresponds to the location of a V-shaped wedge of SSEA-1-positive cells. An arrow points to an axon that appears to have grown around the anterior tip of the "V." $B$ and $C$, Frontal sections through the preparation shown in Figure $3 D$. $B$, Section containing a growth cone that has just crossed the midline. $C, 150 \mu \mathrm{m}$ caudal to $B$. Optic axons course under a canopy of SSEA-1positive processes. Scale bars: $A, 100 \mu \mathrm{m} ; B$ and $C, 25 \mu \mathrm{m}$. 

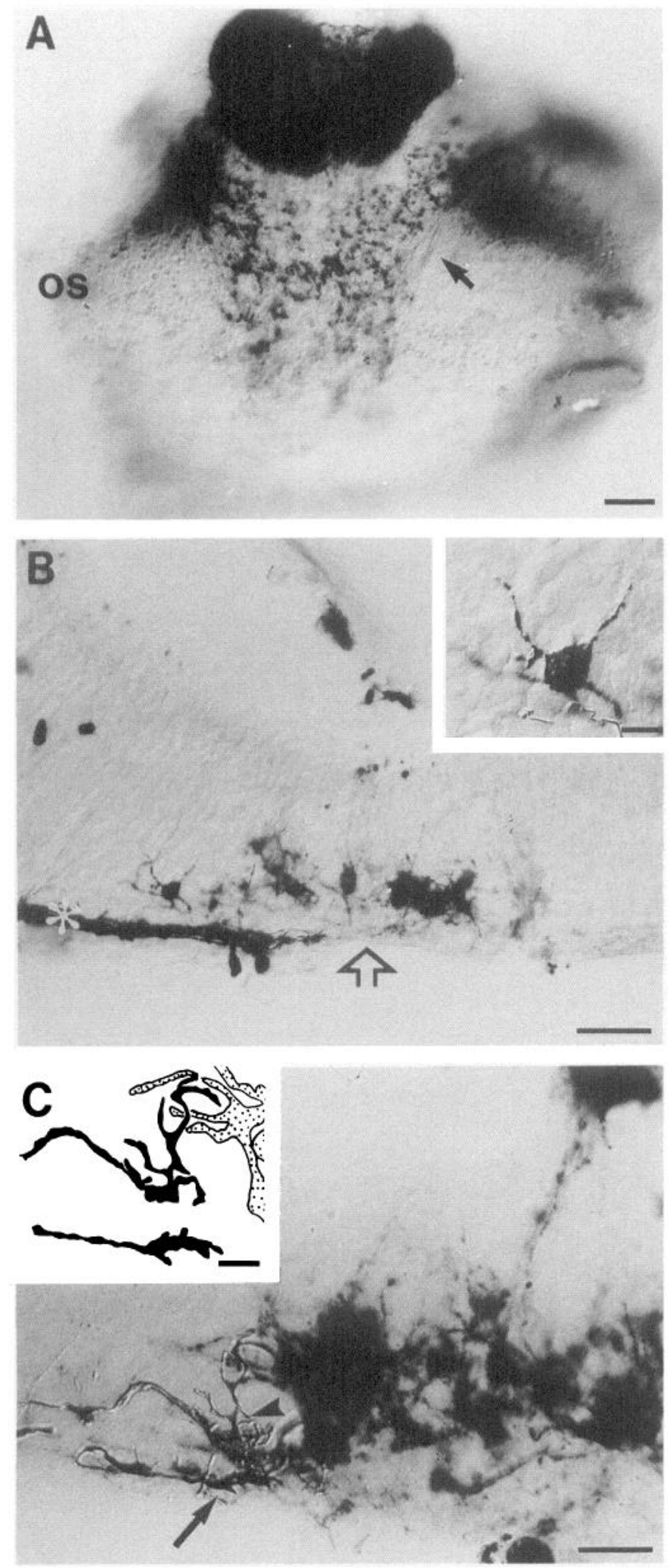

Figure 8. SSEA-1-positive cells in the developing ventral diencephalon. A, Wholemount of an E11.5 embryo immunolabeled with an antibody against SSEA-1. Anterior is toward the bottom of the micrograph. SSEA-1-positive cells are present in the mid- to caudal portions of the ventral diencephalon, and processes from these cells course caudally in the direction of the future optic tracts (arrow). $B$ and $C$, Frontal sections from two different E12.75 embryos containing both DiI, photoconverted axons and SSEA-1-immunolabeled cells, photographed using DIC optics. $B$, SSEA-1-positive cells are clustered around the mid- closely follows the contours of the SSEA-1-positive pattern of cells (Fig. 9A). Crossing axons turn toward the midline in the posterior chiasm, where the SSEA-1-positive cells are located. Axons do not cross directly over these cells, but curve anteriorly and "around" the anterior tip of the "V"-shaped wedge of cells (e.g., arrow Fig. 9A). Thus, the pattern of growth of crossed axons seen at E12.75-13.5 corresponds to this palette of cells. In contrast, due to their lateral trajectory, uncrossed axons only approach SSEA-1-positive cells after they enter the ipsilateral optic tract.

The relationship of early axons to the SSEA-1-positive cells was further studied in frontal sections of double-labeled preparations first viewed as whole mounts. The majority of DiI-labeled axons are located along the pial surface of the brain, ventral to the SSEA-1-labeled cells (Fig. 9B,C). Thus, instead of growing along the SSEA-1-positive template, optic axons course under and around them en route to the contralateral side of the brain. The correspondence between the location of these cells, both with respect to where crossed axons turn medially and to their subsequent trajectory, suggests that these cells may be inhibitory to optic axon growth, thereby demarcating a boundary that defines the paths of early crossed axons.

From our light microscopic examination we are unable to determine whether optic axons contact processes of the SSEA-1positive cells. A few SSEA-1-positive processes extend into the subpial zone in the optic chiasm and developing optic tracts, especially near the rostral tip of the V-shaped wedge (e.g., Fig. $9 A$ ). Occasionally, retinal growth cones were observed deep to the pial suface, where they appear to extend along the border of SSEA-1-positive cells (Fig. 8C). These growth cones have complex morphologies, similar to growth cone forms observed in the chiasm at later ages (Godement et al., 1990) and in vitro at the border of preferred and nonpreferred substrates (Burmeister and Goldberg, 1988).

Early differentiating neurons in the ventral diencephalon. $\mathrm{Re}$ cent studies using neuron-specific antibodies have revealed an early-differentiating population of neurons in the developing ventral diencephalon. During the early period of optic axon growth into the chiasm, the neuronal markers MAP2, $\beta$-tubulin, and L1 label cells that overlap in expression with the CD44positive cells described above (Sretavan et al., 1994). Because the SSEA-1-positive cells described in this study are a subset of the CD44-positive cells, it follows that the SSEA-1-positive cells are also neuronal. In addition, starting at E9.5, neuronspecific $\beta$-tubulin reveals a cluster of cells located at the base of the optic stalk (Easter et al., 1993). These cells appear to be the mouse equivalent of the rat anterobasal nucleus (abn, Altman

$\leftarrow$

line (open arrow), between the ventricular and subpial surfaces. The asterisk indicates the location of photoconverted DiI-labeled axons along the subpial surface. An example of an SSEA-1-positive cell that has a round cell body and multiple processes is shown in the inset. $C$, A growth cone (arrow) located near the subpial surface beneath the SSEA-1-labeled cells, has a simple, streamlined morphology, characteristic of growth cones in paths. A second growth cone (arrowhead) is located deep to the subpial surface, at the border of the SSEA-1positive cells. The complex morphology of this growth cone may reflect interaction with this cell group since such shapes are characteristic of growth cones found in decision regions or at the borders of preferred and non-preferred substrates. The inset is a camera lucida drawing from the actual section in which the growth cones are brown and SSEA-1positive cells are blue (black and stippled, respectively). Scale bars: $A$, $100 \mu \mathrm{m} ; B, 50 \mu \mathrm{m}$; inset $B, 10 \mu \mathrm{m} ; C, 10 \mu \mathrm{m}$; inset $C, 5 \mu \mathrm{m}$. 

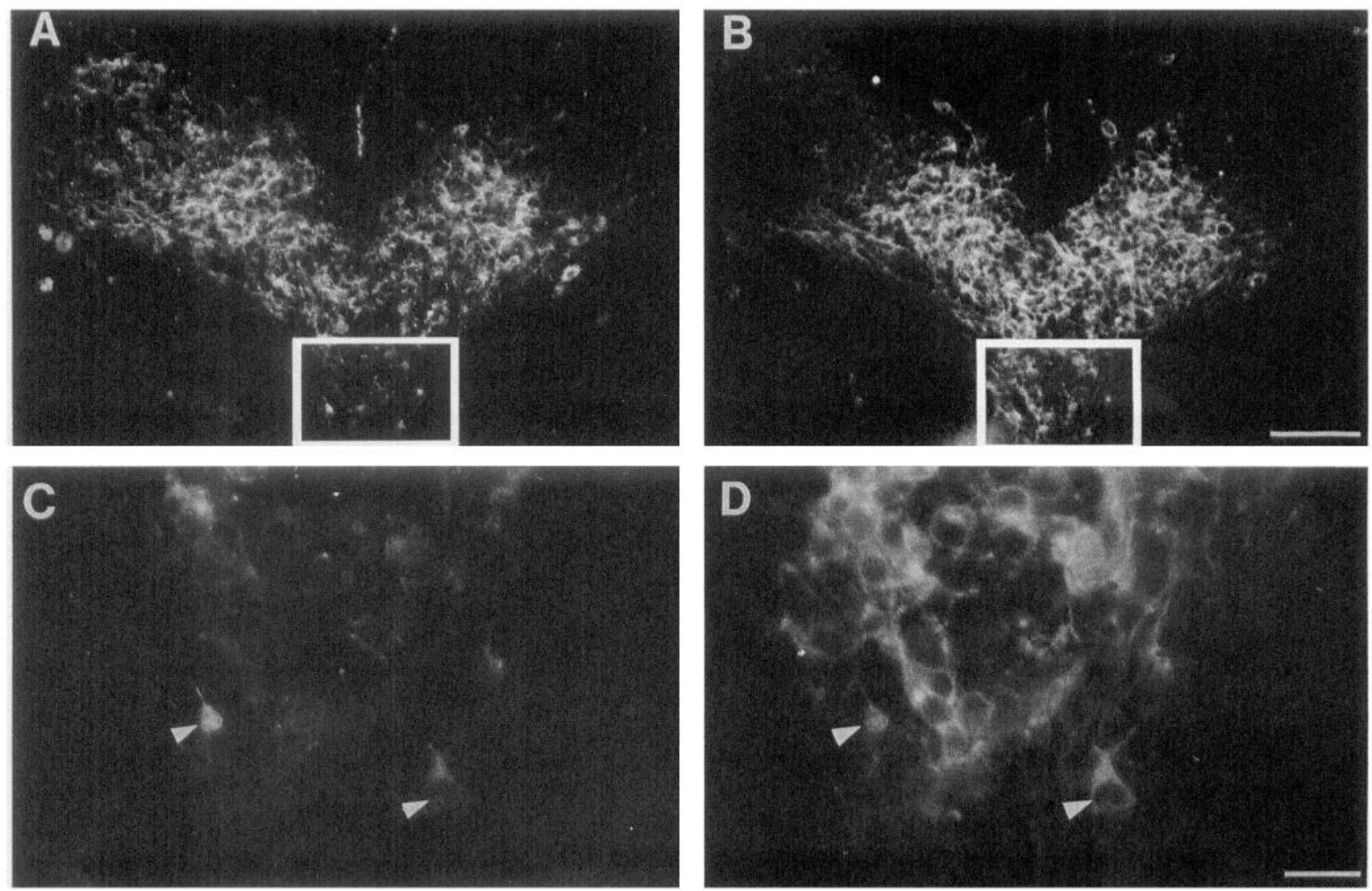

Figure 10. SSEA-1-positive cells are a subset of a population of CD44-positive cells in the developing optic chiasm. Horizontal, frozen section through an E12.5 embryo double-labeled with antibodies against SSEA-1 $(A, C)$ and CD44 $(B, D)$. Both antibodies label a similar, V-shaped wedge of cells (the tip of the $\mathrm{V}$ points anteriorly). $C$ and $D$ show the boxed areas in $A$ and $B$, respectively. Arrowheads point to cells that are both SSEA1- and CD44-positive. Scale bars: $A$ and $B, 100 \mu \mathrm{m} ; C$ and $D, 25 \mu \mathrm{m}$.

and Bayer, 1986), and fibers from the abn course posterolaterally toward the tract of the postoptic commissure (TPOC, Easter et al., 1993). Therefore, we further examined the labeling pattern of $\beta$-tubulin during the period of early optic axon growth into the ventral diencephalon.

At E11.5-12.5 numerous $\beta$-tubulin-positive cells and processes are located in the ventral diencephalon. The position of the $\beta$-tubulin-positive cell bodies is best visualized in frontal sections (Fig. 11). Labeled cells were restricted to either side of the midline in the middle region of the ventral diencephalon and extended further laterally in more caudal regions. Most of the $\beta$-tubulin-positive cell bodies were located midway between the pial and the ventricular surfaces but brightly labeled $\beta$-tubulinpositive cell bodies near the midline were also found within the subventricular zone (Fig. 11B). In sections from E11.5 embryos in which retinal ganglion cells had not yet differentiated and therefore were $\beta$-tubulin negative, no labeled axons were observed in the optic stalk, in contrast to a recent report of an early population of transient retinopetal axons in ferret (Reese and Geller, 1995).

The correspondence between $\beta$-tubulin- and SSEA-1-labeled cells was analyzed in sections double-labeled with both antibodies (Fig. 11). Although all SSEA-1-labeled cells were also $\beta$-tubulin-positive, many $\beta$-tubulin-positive cells were SSEA-1negative. Thus, SSEA-1-positive cells, like the CD44-positive cells, comprise a subset of the $\beta$-tubulin-positive cells present during the initial period of optic axon growth into the ventral diencephalon.

The pattern of SSEA-1-labeled cells at E11.5 is remarkably similar to that described for the abn (for example compare Fig. 8 with Fig. $4 b$ in Easter et al., 1993) suggesting that the SSEA1-positive cells may correspond to this early differentiating population of neurons. Although some SSEA-1-positive cells could be detected at E10.5, consistent labeling of these cells and their processes was not obtained until E11.5, a time when many more $\beta$-tubulin-positive cells are present. Thus, the methods used in this study are unable to distinguish whether SSEA-1 is expressed exclusively by the early-differentiating neurons and processes of the abn and the TPOC. Our analyses do indicate, however, that the trajectories of the first crossed retinal axons in the nascent optic chiasm are bounded by an SSEA-1-positive population of neurons, and that uncrossed axons do not contact them until after they have already reached the ipsilateral optic tract.

In summary, the combination of tract tracing and immunocytochemical methods used in this study has revealed the early pattern of optic axon growth during the establishment of the optic chiasm as well as identified potential loci for cues that contribute to this pattern (see Fig. 12). Within the developing optic chiasm is a specialized cellular arrangement consisting of a palisade of radial glia and a subpopulation of early differentiating neurons that express SSEA-1 and CD44. These latter cells both intersect the glial palisade along its midline and spread out 

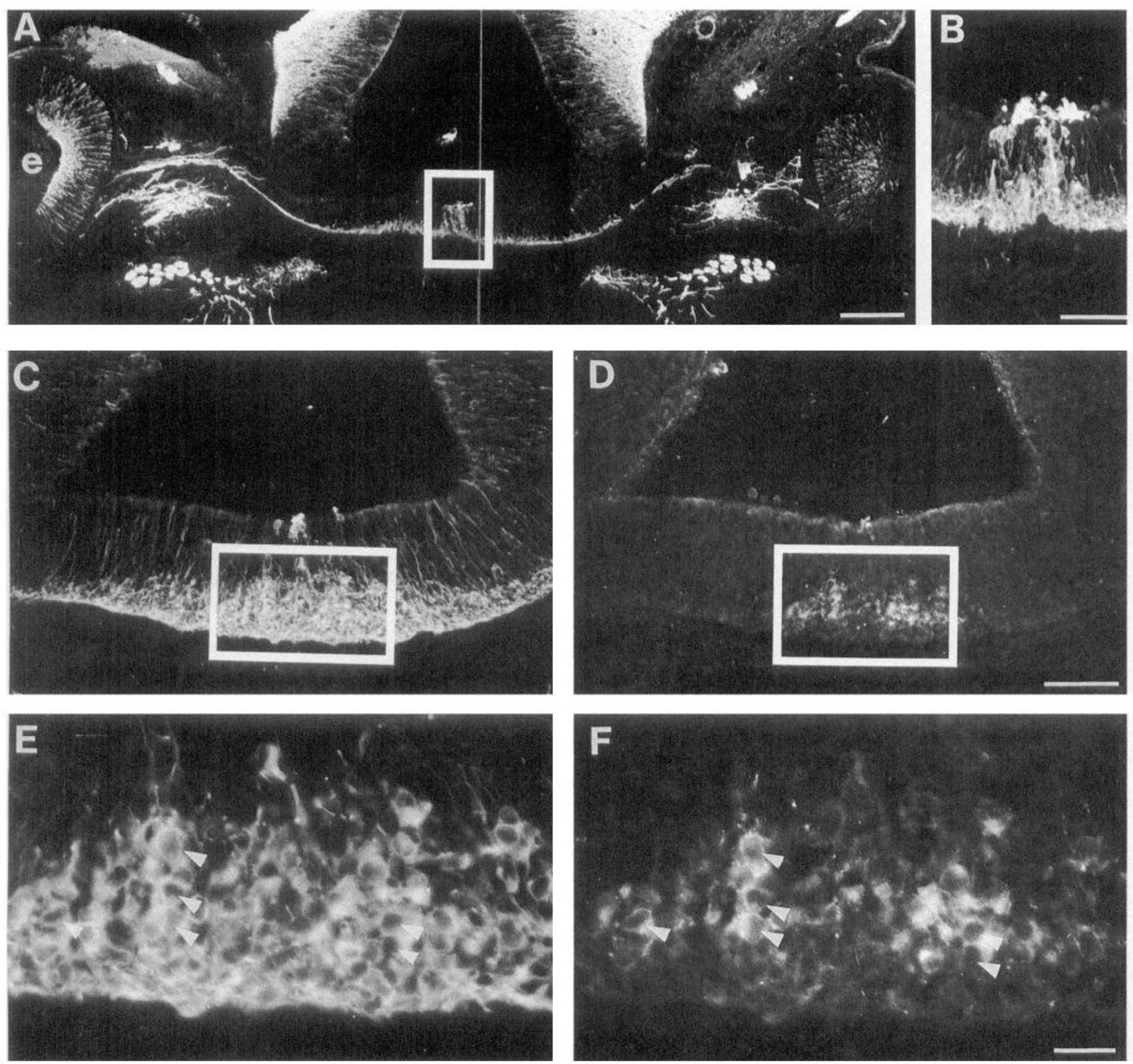

Figure 11. SSEA-1-positive cells are a subpopulation of $\beta$-tubulin-positive neurons in the ventral diencephalon. Frozen, frontal sections through an E12.5 embryo. A, $\beta$-tubulin-labeled cells are clustered around the chiasmatic midline, in the retina (e), and along the lateral walls of the diencephalon. In addition, brightly labeled optic axons (arrow) are seen leaving the eye and growing along the optic stalk and into the ventral diencephalon. $B$, Higher power view of the bracketed region in $A . C-F$, Section $160 \mu \mathrm{m}$ caudal to $A$ double-labeled for $\beta$-tubulin $(C$, $E$ ) and SSEA-1 $(D, F) . E$ and $F$ are higher power views of labeled cells in $C$ and $E$, respectively, and arrowheads show examples of cells that are both SSEA-1- and $\beta$-tubulin-positive. Abbreviation: $e$, eye. Scale bars: $A, 200 \mu \mathrm{m} ; B, 50 \mu \mathrm{m} ; C$ and $D, 100 \mu \mathrm{m} ; E$ and $F, 25 \mu \mathrm{m}$.

along its caudal boundary. All retinal axons grow into the ventral diencephalon and initially extend posteriorly lateral to the RC2positive palisade. Uncrossed axons continue to grow laterally and enter the presumptive optic tract directly. Crossed axons turn medially and enter the radial glial palisade near its caudal border. As the axons enter the palisade many axons turn rostrally, coincident with the rostral boundary of the SSEA-1-positive cells. Crossed axons do not grow among but are located under the SSEA-1-positive cells. The correspondence between the pathways taken by optic axons with cellular components of this specialized cellular arrangement strongly suggests that cells local- ized within the ventral diencephalon are important for the establishment of the visual pathway.

\section{Discussion}

Comparison of early and late periods of growth in the chiasm This study characterizes the earliest optic axon pathways with respect to resident cells and molecules in the ventral diencephalon. Two cellular groupings present during the principal period of optic axon growth in the chiasm (E15-17; Marcus et al., 1995) are arrayed more extensively during early axon ingrowth (E12.5-13.5). Furthermore, the early and late growth patterns 

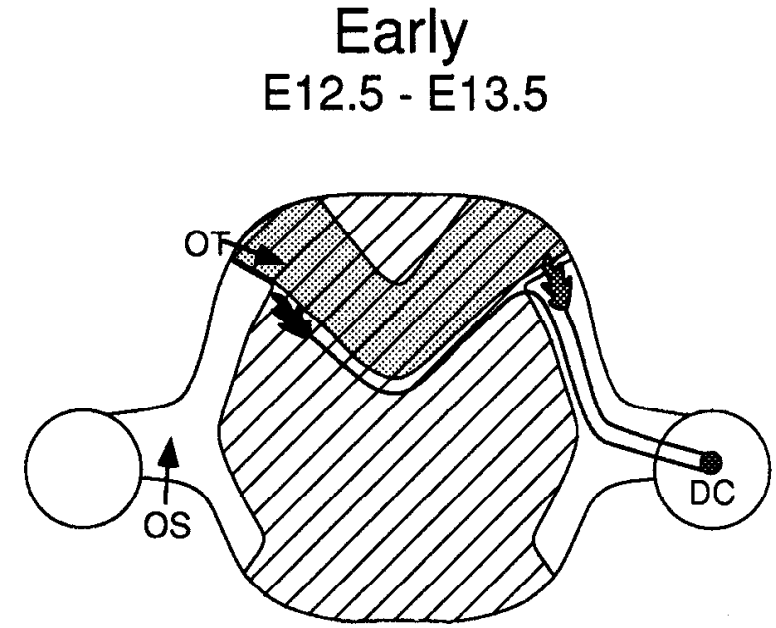

SSEA-1

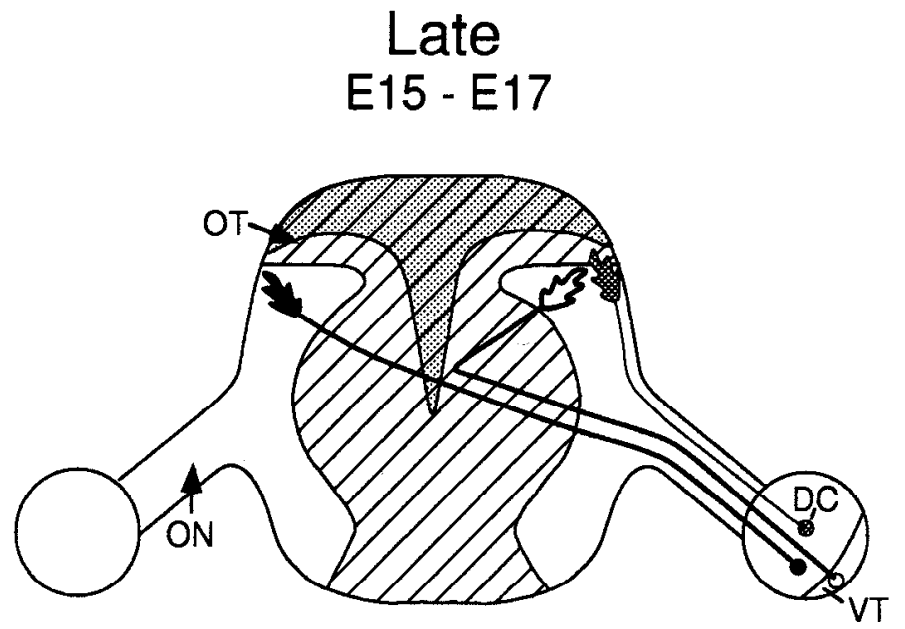

\section{$\square \mathrm{RC2}$}

Figure 12. Summary diagram contrasting the paths of early (E12.5-13.5) and later-growing (E15-17) optic axons in relationship to cells in the developing optic chiasm. Early uncrossed axons, originating in dorsocentral retina, enter the ipsilateral optic tract directly while late uncrossed axons, originating in ventrotemporal retina, first grow toward the midline. Early uncrossed axons never enter the radial glial palisade while early crossed axons enter along its caudal border. Later crossed and uncrossed optic axons enter the rostral half of the radial glial palisade. Early crossed axons turn medially and rostrally along the rostral border of SSEA-1-positive neurons. The conformation of SSEA-1-positive neurons elongates rostrocaudally and late crossed and uncrossed axons encounter these neurons only near the midline. Finally, fiber-fiber interactions, which affect late uncrossed axons, are not involved in the establishment of the early ipsilateral pathway. Scc text for details. Abbreviations: $D C$, dorsocentral retina; $O N$, optic nerve; $O S$, optic stalk; $O T$, optic tract; $V T$, ventrotemporal retina.

differ in five respects. First, unlike later uncrossed axons whose growth cones approach the midline before turning sharply back toward the ipsilateral optic tract (Godement et al., 1990, 1994; Sretavan, 1990), early uncrossed axons enter the ipsilateral optic tract directly in the lateral ventral diencephalon. Second, whereas at E15-17 crossed and uncrossed fibers grow toward the midline within a radial glial palisade, at E12.5-13.5 all axons initially grow lateral to the palisade, and pioneering uncrossed axons never enter it. Third, while at E15-17 growth cones of crossed axons invade the rostral half of the palisade, pioneering crossed axons enter it caudally. Fourth, pioneering crossed axons course along a border of SSEA-1-positive cells, resulting in a circuitous route to the midline. Later, crossed axons grow more directly toward the contralateral optic tract, only encountering a raphe of SSEA-1-positive cells at the midline. Finally, the first axons enter the ipsilateral optic tract prior to interactions between fibers from each eye, indicating that these interactions are not necessary for the establishment of the early ipsilateral pathway. Fiber-fiber interactions are important, however, for the adult retinal projection patterns since removal of one eye early in embryonic development results in a decreased ipsilateral projection (Godement et al., 1987a) and following enucleation at E13 ipsilateral, ventrotemporal fibers from the remaining eye stall in the midline zone (Godement et al., 1990; Godement unpublished observations; but also see Sretavan and Reichardt, 1993).

An unresolved issuc is whether developmental morphogenetic transformations can explain the different axonal projection patterns early versus late. For example, the different configurations of resident cells during development may simply reflect their rearrangement during embryonic morphogenesis. We propose that these changes can not explain the extreme differences in the uncrossed projection: early, directly into the optic tract, and later, entry into the midline zone before turning back ipsilaterally. Moreover, the different paths of crossed and uncrossed axons, and the altered configurations of the resident cells during the early and late periods, indicate that the degree of interaction between axons and resident cells may differ during these periods.

Interestingly, the earliest ipsilateral projection derives from dorsocentral and not ventrotemporal retina (Dräger, 1985; Godement et al., 1987b, 1990; Colello and Guillery, 1990; Sretavan, 1990). Retrograde labeling in the adult does not reveal the uncrossed dorsocentral cells, raising what roles these cells play during development. One possibility is that they are pioneers important for establishing the visual projection (Sretavan, 1990). While in many systems the mature nervous system arises from an adultlike pattern established early in development (Keshishian and Bentley, 1983; Landmesser, 1991), a transient retinal projection, like the subplate, may set the stage for later, distinctly different growth patterns (Allendoerfer and Shatz, 1994). Alternatively, early uncrossed axons may enter the ipsilateral optic tract due to their lateral location in the ventral diencephalon, and not due to specific guidance cues. Early ipsilateral fibers would then constitute pathfinding "errors" that are eliminated during the normal process of retinal ganglion cell death (Jeffery and Perry, 1982; Martin et al., 1983; Guillery et al., 1995). Our results do not address whether the earliest ipsilateral path from dorsocentral retina is necessary for development of the adult visual projection.

\section{Axonal growth and the cellular environment}

Glial cells can play permissive or inhibitory roles during pattern formation and the establishment of neural pathways. In verte- 
brates, growth cones extend among radial neuroepithelial or glial endfeet at the pial surface, suggesting that glia provide permissive substrates for axon growth (e.g., Silver and Rutishauser, 1984; Kuwada, 1986; Marcus and Easter, 1995). Consistent with these studies, growth cones of optic axons course among the subpial endfeet of RC.2-positive cells within the palisade and optic tracts.

Glial cells also form boundaries inhibiting axons from entering inappropriate brain regions (Silver et al., 1987, 1993; Snow et al., 1990; Trevarrow et al., 1990; Carpenter and Bastiani, 1991; Steindler, 1993; Jhaveri, 1994; Marcus and Easter, 1995). Early optic axon growth lateral to the RC2-positive palisade is consistent with it presenting such a boundary. However, since crossed axons eventually enter and traverse the palisade, this zone must be less permissive and not refractory to axon growth.

Neurons may also guide axons. Fasciculation of axons with earlier established pathways occurs in insects (Raper et al., 1983) and vertebrates (Kuwada, 1986; Dodd and Jessell, 1988). Contact with "preexisting" fibers may also help establish the visual projections. Beginning at E9.5, neurons which are the mouse equivalent of the rat anterobasal nucleus (Altman and Bayer, 1986), are positioned at the base of the optic stalk. Processes from these cells form the mouse homologue of the tract of the postoptic commissure in embryonic Xenopus (Easter and Taylor, 1989) and zebrafish (Chitnis and Kuwada, 1990; Wilson et al., 1990; Ross et al., 1992). Because the first optic axons enter the brain after E12.5, cells and axons of the abn and TPOC potentially provide guidance information for pioneering retinal fibers.

During early retinal axon growth, SSEA-1-positive cells are arrayed similarly to cells and processes of the abn and TPOC. The correspondence between the meandering early crossed pathway and the rostral border of these cells (Fig. 9A) suggests they may provide guidance information. While these cells may be a posterior boundary for early crossed and uncrossed fibers, this is not true later. In contrast to the V-shaped wedge of cells at E12.5-E13.5, at E15-17, SSEA-1-positive cells form a broad band caudal to the chiasm itself, from which a raphe extends rostrally (Marcus et al., 1995). Because at later ages, crossed and uncrossed fibers approach the midline in the rostral half of the chiasm, optic axons encounter SSEA-1-positive cells only if they cross or approach the midline while turning. Thus, optic axons entering the chiasm later in development are spatially segregated from cues that may influence early optic axon trajectory.

The SSEA-1-positive cells are a subset of the CD44-positive cells previously identified (Sretavan et al., 1994). CD44 is a cell surface molecule involved in cell-cell interactions in the immune system (Denning et al., 1990; Tanaka et al., 1993). CD44 may inhibit retinal axon growth, as CD44-expressing cell lines dampen retinal axon growth in vitro (Sretavan et al., 1994). SSEA-1, like CD44, is a glycoprotein present in the immune (Kerr and Stocks, 1992) and nervous sytems (Dodd and Jessell, 1985; Oudega et al., 1992). Growth of early crossed axons along the SSEA-1- and CD44-expressing neurons, rather than into the more accessible ipsilateral optic tract, suggests that a combination of inhibitory and attractive cues guide crossed axons in the chiasm (see Figs. 5 and 12): First, consistent with the in vitro CD44 results, SSEA-1- and CD44-expressing neurons may guide crossed axons by forming a barrier adjacent to a more permissive path. Second, an attractive cue, such as that demonstrated for the floor plate (Tessier-Lavigne et al., 1988), would lure axons away from the ipsilateral optic tract, toward the midline, and around these inhibitory cells.

\section{Similarities between early growth and the marsupial chiasm}

In the marsupial, early monocular enucleation does not alter the ipsilateral projections from the remaining eye (Méndez-Otero et al., 1986; Coleman and Beazley, 1989). Likewise, in mouse, the early ipsilateral pathway forms in the absence of fiber-fiber interactions important at later ages. Another similarity between the marsupial and the earliest axons in mouse is that uncrossed axons separate from crossed axons before entering the chiasm itself (Jeffery and Harman, 1992), at an interface between interfascicular optic nerve glia and radial glia in the ventral diencephalon (Bodian, 1936; Taylor and Guillery, 1994). This interface may be analogous to the lateral border formed by the radial glial palisade that is not entered by early uncrossed fibers in mouse. At later ages in the mouse uncrossed axons diverge from crossed axons within the palisade. Thus, in contrast to early uncrossed axons in mouse and uncrossed axons in marsupials, uncrossed axons of the mature cuthcrian visual pathway recognize cues localized within a midline glial structure (Godement et al., 1990, 1994; Sretavan and Reichardt, 1993; Wizenmann et al., 1993; Marcus et al., 1995).

In summary, analysis of the early pattern of optic axon growth suggests that mechanisms that shape crossed and uncrossed axonal trajectories differ during the establishment and subsequent development of the visual pathways. The definition of the identity and stage-specific arrangement of cells resident to the diencephalon will facilitate the investigation of these mechanisms, as well as the patterns of gene expression directing them.

\section{Note added in proof:}

With the aim of ablating the conformation of early differentiating neurons, Sretavan et al. (1995) injected antibodies against CD44 plus complement into E11 embryos. Four days later, all retinal axons had stalled after exiting the optic stalks and failed to generate a chiasm. This data supports the hypothesis that resident cells of the diencephalon are important for growth of retinal axons during the initial formation of the chiasm.

\section{References}

Allendoerfer KL, Shatz CJ (1994) The subplate, a transient neocortical structure: its role in the development of connections between thalamus and cortex. Annu Rev Neurosci 17:185-218.

Altman J, Bayer SA (1986) The development of the rat hypothalamus. Adv Anat Embryol Cell Biol 100:1-178.

Baker GE, Colello RJ (1994) The origin and course of retinofugal axons during normal development of the ferret. Soc Neurosci Abstr 20:1085.

Bodian D (1936) An experimental study of the optic tracts and retinal projection of the Virginia opossum. J Comp Neurol 66:113-144.

Carpenter EM, Bastiani MJ (1991) Developmental expression of REGA-1, a regionally expressed glial antigen in the central nervous system of grasshopper embryos. J Neurosci 11:277-286.

Chan SO, Baker GE, Guillery RW (1993) Differential action of the albino mutation on two components of the rat's uncrossed retinofugal pathway. J Comp Neurol 336:362-377.

Chan SO, Guillery RW (1993) Developmental changes produced in the retinofugal pathways of rats and ferrets by early monocular enucleations: the effects of age and the differences between normal and albino animals. J Neurosci 13:5277-5293.

Chédotal A, Pourquié O, Sotelo C (1995) Initial tract formation in the brain of the chick embryo: selective adhesion of the BEN/SC1/DMGRASP cell adhesion molecule. Eur J Neurosci 7:198-212.

Chitnis AB, Kuwada JY (1990) Axonogenesis in the brain of zebrafish embryos. J Neurosci 10:1892-1905. 
Colello RJ, Guillery RW (1990) The early development of retinal ganglion cells with uncrossed axons in the mouse: retinal position and axon course. Development 108:515-523.

Coleman LA, Beazley LD (1989) Retinal ganglion cell number is unchanged in the remaining eye following early unilateral eye removal in the wallaby Setonix brachyurus, quokka. Dev Brain Res 48:293307.

Denning SM, Le PT, Singer KH, Haynes BF (1990) Antibodies against the CD44 p80, lymphocyte homing receptor molecule augments human peripheral blood T cell activation. J Immunol 144:7-15.

Dodd J, Jessell TM (1985) Lactoseries carbohydrates specify subsets of dorsal root ganglion neurons projecting to the superficial dorsal horn of rat spinal cord. J Neurosci 5:3278-3294.

Dodd J, Jessell TM (1988) Axonal guidance and the patterning of neuronal projections in vertebrates. Science 242:692-699.

Dräger UC (1985) Birth dates of retinal ganglion cells giving rise to the crossed and uncrossed optic projections in the mouse. Proc R Soc Lond [Biol] 224:57-77.

Easter SS Jr, Taylor JSH (1989) The development of the Xenopus retinofugal pathway: optic fibers join a pre-existing tract. Development 107:553-573.

Easter SS Jr, Ross LS, Frankfurter A (1993) Initial tract formation in the mouse brain. J Neurosci 13:285-299.

Easter SS Jr, Burrill J, Marcus RC, Ross LS, Taylor JSH, Wilson SW (1994) Initial tract formation in the vertebrate brain. Prog Brain Res 102:79-93.

Figdor M, Stern CD (1993) Segmental organization of embryonic diencephalon. Nature 363:630-633.

Godement P, Salaün J, Métin C (1987a) Fate of uncrossed retinal projections following early or late prenatal monocular enucleation in the mouse. J Comp Neurol 255:97-109.

Godement P, Vanselow J, Thanos S, Bonhoeffer F (1987b) A study in developing visual systems with a new method of staining neurones and their processes in fixed tissue. Development 101:697-713.

Godement P, Salaün J, Mason CA (1990) Retinal axon pathfinding in the optic chiasm: divergence of crossed and uncrossed fibers. Neuron 5:173-196.

Godement P, Wang L-C, Mason CA (1994) Retinal axon divergence in the optic chiasm: dynamics of growth cone behavior at the midline. J Neurosci 14:7024-7039.

Guillery RW (1982) The optic chiasm of the vertebrate brain. Contrib Sensory Physiol 7:39-73.

Guillery RW, Walsh C (1987) Changing glial organization relates to changing fiber order in the developing optic nerve of ferrets. J Comp Neurol 265:203-217.

Guillery RW, Mason CA, Taylor JSH (1995) Developmental determinants at the mammalian optic chiasm. J Neurosci 15:4727-4737.

Hatini V, Tao W, Lai E (1994) Expression of winged helix genes, BF-1 and BF-2, define adjacent domains within the developing forebrain and retina. J Neurobiol 25:1293-1309.

Jeffery G, Harman AM (1992) Distinctive pattern of organisation in the retinofugal pathway of a marsupial. II. Optic chiasm. J Comp Neurol 325:57-67.

Jeffery G, Perry VH (1982) Evidence for ganglion cell death during development of the ipsilateral retinal projection in the rat. Dev Brain Res 2:176-180.

Jhaveri S (1994) The midline glia of the tectum: a barrier for developing retinal axons. Perspect Dev Neurobiol 1:237-243.

Kaprielian Z, Patterson PH (1994) The molecular basis of retinotectal topography. Bioessays $16: 1-11$.

Kerr MA, Stocks S (1992) The role of CD15-(Lex)-related carbohydrates in neutrophil adhesion. Histochem J 24:811-826.

Keshishian H, Bentley D (1983) Embryogenesis of peripheral nerve pathways in grosshopper legs. I. The initial nerve pathway to the CNS. Dev Biol 96:89-102.

Knowles BB, Rappaport J, Solter D (1982) Murine embryonic antigen (SSEA-1) is expressed on human cells and structurally related human blood group antigen I is expressed on mouse embryos. Dev Biol 93: $54-58$.

Kuwada JY (1986) Cell recognition by neuronal growth cones in a simple vertebrate model. Science 233:740-746.

Landmesser L (1991) Growth cone guidance in the avian limb: a search for cellular and molecular mechanisms. In: The nerve growth cone (Kater SB, Letourneau P, Macagno E, eds), pp 373-385. New York: Raven.
Lee MK, Tuttle JB, Rebhun LI, Cleveland DW, Frankfurter A (1990) The expression and posttranslational modification of a neuron-specific b-tubulin isotype during chick embryogenesis. Cell Motil Cytoskel 17:118-132.

Macdonald R, Xu Q, Barth KA, Mikkola I, Holder N, Fjose A, Krauss S, Wilson SW (1994) Regulatory gene expression boundaries demarcate sites of neuronal differentiation in the embryonic zebrafish forebrain. Neuron 13:1039-1053.

Marcus R, Blazeski R, Godement P, Mason CA (1995) Retinal axon divergence in the optic chiasm: uncrossed axons diverge from crossed fibers within a midline glial specialization. J Neurosci 15:3716-3729.

Marcus RC, Easter SS Jr (1995) The expression of glial fibrillary acidic protein and its relation to tract formation in embryonic zebrafish $(\mathrm{Da}$ nio rerio). J Comp Neurol, in press.

Martin PR, Sefton AJ, Dreher B (1983) The retinal location and fate of ganglion cells which project to the ipsilateral superior colliculus in neonatal albino and hooded rats. Neurosci Lett 41:219-226.

Méndez-Otero R, Rocha-Miranda CE, Carvalho-Dias E (1986) Effects of monocular enucleation at different stages of development on the uncrossed retinocollicular projection in the opossum. Dev Brain Res 27:101-108.

Misson J-P, Edwards MA, Yamamoto M, Caviness VS (1988) Identification of radial glial cells within the developing murine cerebral wall: studies based upon a new histochemical marker. Dev Brain Res 44:95-108.

Oudega M, Marani E, Thomeer RTWM (1992) Transient expression of stage-specific embryonic antigen-I (CD15) in the developing dorsal rat spinal cord. Histochem J 24:869-877.

Puelles L, Rubenstein JLR (1993) Expression patterns of homeobox and other putative regulatory genes in the embryonic mouse forebrain suggest a neuromeric organization. Trends Neurosci 16:472-479.

Raper JA, Bastiani MJ, Goodman CS (1983) Pathfinding by neuronal growth cones in grasshopper embryos. II. Selective fasciculation onto specific axonal pathways. J Neurosci 3:31-41.

Reese BE, Geller SF (1995) Precocious invasion of the optic stalk by transient retinopetal axons. J Comp Neurol 353:572-584.

Rice DS, Williams, RW, Goldowitz D (1995) Genetic control of retinal projections in inbred strains of albino mice. J Comp Neurol 354:459469.

Ross LS, Parrett T, Easter SS Jr (1992) Axonogenesis and morphogenesis in the embryonic zebrafish brain. $J$ Neurosci $12: 467-482$.

Savitt JM, Trisler D, Hilt DC (1995) Molecular cloning of TOP ${ }_{\mathrm{AP}}$ : a topographically graded protein in the developing chick visual system. Neuron 14:253-261.

Silver J (1984) Studies on the factors that govern directionality of axonal growth in the embryonic optic nerve and at the chiasm of mice. J Comp Neurol 223:238-251.

Silver J, Rutishauser U (1984) Guidance of optic axons in vivo by a preformed adhesive pathway on neuroepithelial endfeet. Dev Biol 106:485-499.

Silver J, Poston M, Rutishauser U (1987) Axon pathway boundaries in the developing brain. I. Cellular and molecular determinants that separate the optic and olfactory projections. J Neurosci 7:2264-2272.

Silver J, Edwards MA, Levitt P (1993) Immunocytochemical demonstration of early appearing astroglial structures that form boundaries and pathways along axon tacts in the fetal brain. J Comp Neurol 328 415-436.

Snow DM, Steindler DA, Silver J (1990) Molecular and cellular characterization of the glial roof plate of the spinal cord and optic tectum: a possible role for a proteoglycan in the development of an axon barrier. Dev Biol 138:359-376.

Solter D, Knowles BB (1978) Monoclonal antibody defining a stagespecific mouse embryonic antigen (SSEA-1). Proc Natl Acad Sci USA 75:5565-5569.

Sretavan DW (1990) Specific routing of retinal ganglion cell axons at the mammalian optic chiasm during embryonic development. J Neurosci 10:1995-2007.

Sretavan DW (1993) Pathfinding at the mammalian optic chiasm. Curr Opin Neurobiol 3:45-52.

Sretavan DW, Reichardt LF (1993) Time-lapse video analysis of retinal ganglion cell axon pathfinding at the mammalian optic chiasm: growth cone guidance using intrinsic chiasm cues. Neuron 10:761777.

Sretavan DW, Feng L, Pure E, Reichardt LF (1994) Embryonic neurons of the developing optic chiasm express L1 and CD44, cell surface 
molecules with opposing effects on retinal axon growth. Neuron 12 957-975.

Sretavan DW, Pure E, Siegel MW, and Reichardt LF (1995) Disruption of retinal axon ingrowth by ablation of embryonic mouse optic chiasm neurons. Science 269:98-101.

Steindler DA (1993) Glial boundaries in the developing nervous system. Annu Rev Neurosci 16:445-470.

Takahashi R, Misson J-P, Caviness VS Jr (1990) Glial process elongation and branching in the developing murine neocortex: a qualitative and quantitative immunohistochemical analysis. J Comp Neurol 302:15-28.

Tanaka Y, Adams DH, Hubscher S, Hirano H, Siebenlist U, Shaw S (1993) Proteoglyclan-immobilized MIP-1B induces adhesion of $T$ cells. Nature 61:79-82.

Taylor JSH, Guillery RW (1994) Early development of the optic chiasm in the gray short-tailed opossum, Monodelphis domestica. J Comp Neurol 350:109-121.

Tessier-Lavigne M, Placzek M, Lumsden AGS, Dodd J, Jessell TM
(1988) Chemotropic guidance of developing axons in the mammalian central nervous system. Nature 336:775-778.

Tole S, Patterson PH (1995) Regionalization of the developing forebrain: a comparison of FORSE-1, Dlx-2, and BF-1. J Neurosci 15: 970-980.

Trevarrow B, Marks DL, Kimmel CB (1990) Organization of hindbrain segments in the zebrafish embryo. Neuron 4:669-679.

Wilson SW, Easter SS Jr (1991) A pioneering growth cone in the embryonic zebrafish brain. Proc Natl Acad Sci USA 88:2293-2296.

Wilson SW, Ross LS, Parrett T, Easter SS Jr (1990) The development of a simple scaffold of axon tracts in the brain of the embryonic zebrafish, Brachydanio rerio. Development 108:121-145.

Wilson SW, Placzek M, Furley A (1993) Border disputes: do boundaries play a role in growth cone guidance? Trends Neurosci 16:316322.

Wizenmann A, Thanos S, Boxberg YV, Bonhoeffer F (1993) Differential reaction of crossing and non-crossing rat retinal axons on cell membrane preparations from the chiasm midline: an in vitro study. Development 117:725-735 